\title{
Botulinum Toxin for the Treatment of Hemifacial Spasm: An Update on Clinical Studies
}

\author{
Nicola Tambasco ${ }^{1,2, *(\mathbb{C}}$, Marta Filidei ${ }^{2}$, Pasquale Nigro ${ }^{1} \oplus$, Lucilla Parnetti ${ }^{2} \mathbb{D}$ and Simone Simoni ${ }^{2}$ \\ 1 Movement Disorders Center, Neurology Department, Perugia General Hospital and University of Perugia, \\ 06129 Perugia, Italy; pasquale.nigro1987@gmail.com \\ 2 Neurology Department, Perugia General Hospital and University of Perugia, 06129 Perugia, Italy; \\ martafilidei91@gmail.com (M.F.); lucilla.parnetti@unipg.it (L.P.); simonesimoni84@gmail.com (S.S.) \\ * Correspondence: n.tambasco@libero.it
}

check for

updates

Citation: Tambasco, N.; Filidei, M.; Nigro, P.; Parnetti, L.; Simoni, S. Botulinum Toxin for the Treatment of Hemifacial Spasm: An Update on Clinical Studies. Toxins 2021, 13, 881. https://doi.org/10.3390/ toxins 13120881

Received: 1 November 2021

Accepted: 2 December 2021

Published: 9 December 2021

Publisher's Note: MDPI stays neutral with regard to jurisdictional claims in published maps and institutional affiliations.

Copyright: (c) 2021 by the authors. Licensee MDPI, Basel, Switzerland. This article is an open access article distributed under the terms and conditions of the Creative Commons Attribution (CC BY) license (https:// creativecommons.org/licenses/by/ $4.0 /)$.

\begin{abstract}
Hemifacial spasm (HFS) is a movement disorder characterized by involuntary contractions of the facial muscles innervated by the seventh cranial nerve. Generally, it is associated with a poor quality of life due to social embarrassment and can lead to functional blindness. Moreover, it is a chronic condition, and spontaneous recovery is rare. Intramuscular injections of Botulinum Toxin (BoNT) are routinely used as HFS treatment. Methods: We reviewed published articles between 1991 and 2021 regarding the effectiveness and safety of BoNT in HFS as well as any reported differences among BoNT formulations. Results: The efficacy of BoNT for HFS treatment ranged from 73\% to $98.4 \%$. The mean duration of the effect was around 12 weeks. Effectiveness did not decrease over time. Adverse effects were usually mild and transient. The efficacy and tolerability of the different preparations appeared to be similar. Among the studies, dosage, injected muscles, intervals of treatment, and rating scales were variable, thus leading to challenges in comparing the results. Conclusions: BoNT was the treatment of choice for HFS due to its efficacy and safety profile. Further studies are needed to investigate the factors that influence the outcome, including the optimal timing of treatment, injection techniques, dosage, and the best selection criteria for formulations.
\end{abstract}

Keywords: hemifacial spasm; botulinum toxin; BoNT; spasm; onabotulinum toxin; abobotulinum toxin

Key Contribution: Botulinum toxin is reported as the most efficacious therapy for hemifacial spasm. Clinical studies regarding effectiveness and safety of botulinum toxin are presented.

\section{History Presentation and Epidemiology}

Hemifacial spasm (HFS) is a hyperkinetic movement disorder characterized by short or persistent, intermittent synchronous twitching of the muscles innervated by the facial nerve [1], which is a chronic condition, and spontaneous recovery is rare [2,3]. Typical features include involuntary clonic and/or tonic contractions of the muscles of facial expression, usually unilaterally, initiating in the periorbital musculature, progressing to involve the perioral, platysma, and other muscles of facial expression $[1,4]$. HFS interferes with social life in about $90 \%$ of patients, leading to isolation and even depression, there, in turn, having a negative impact on the quality of life [5]. Therefore, early diagnosis and optimal therapy are generally necessary.

HFS was described for the first time by F. Schultze, in 1875, in a 56-year-old male having involuntary movements involving the left side of his face with post-mortem examination of a giant aneurysm of the left vertebral artery compressing the left facial nerve [6]. The condition received its current terminology by Babinski in 1905 [7].

Currently, HFS is classified as primary (79\%) or secondary to facial nerve damage (21\%) [8]. The former is attributed to the compression of the facial nerve at the root exit zone in the brainstem, usually by an ectatic or aberrant blood vessel [8,9]. Instead, the latter has been associated with a number of conditions, including cerebellopontine 
angle tumors, acoustic neuroma or meningioma, epidermoid, arachnoid cyst, lipoma, arteriovenous malformations; brainstem lesions (stroke, trauma, demyelinating disorders, tumors), infections (otitis media, tubercular meningitis), structural abnormalities of the posterior cranial fossa (Paget's disease, Chiari malformation); parotid tumors; and Bell's palsy [10].

The mean prevalence of the disorder is around 10 in 100,000 (14.5 and 7.4 per 100,000 in females and males, respectively) [11,12]. The average age at onset of primary HFS ranges from the fifth to sixth decades of life [8]. HFS is commonly sporadic, with a few familial cases having been reported $[13,14]$. Likewise, the bilateral disease is also rare $(2.6 \%)$, and when it does present it, begins unilaterally, progressing to involve the other side [15].

Diagnosis of HFS is mainly based on clinical recognition. Additionally, detailed patient history and a neurological examination are required to exclude any signs which might suggest an underlying secondary cause. Currently, available diagnostic work-up includes electromyography to exclude denervation due to facial nerve lesions, as well as brain MRI to rule out any demyelination or space-occupying lesions near the brainstem [16]. The distinction between primary or secondary HFS is fundamental to properly direct the treatment strategy. Indeed, whereas the management of primary HFS reduces the patient's symptoms and eventually can lead to consistently resolute the clinical picture, in secondary HFS, the focus should be first at identifying and treating the underlying cause. Differential diagnosis of HFS needs to be made for blepharospasm, tardive dyskinesias, motor tics, psychogenic HFS, focal cortical seizures involving the facial muscles, and aberrant regeneration after facial nerve injury.

Among the available clinical scales, the Hemifacial Spasm Grading Scale (HSGS) is regarded as an objective, quick and reliable tool for the assessment of HFS, based upon motor signs which are useful for monitoring Botulinum toxin (BoNT) treatment efficacy over time [17]. Differently, the seven-item HFS-7 measures the quality of life, but none of the motor skills [18]. Moreover, the HFS Score has been developed by incorporating both motor and subjective features [19].

Several drugs have been studied for the treatment of HFS, such as anticonvulsants including carbamazepine, clonazepam, gabapentin, and others including baclofen, anticholinergics, and haloperidol [1]. Reliable data on the efficacy of oral treatment has been limited, and numerous side effects have been reported, such as sedation and fatigue [20].

Concerning treatment, the most efficacious therapy has been reported to be BoNT, a biological toxin derived from the Clostridium botulinum $[2,21]$. It is active on the presynaptic region of the neuromuscular junction, inhibiting the calcium-mediated release of acetylcholine at the nerve terminal, therein avoiding impulse generation downstream, resulting in neuroparalysis [22].

The regulation of a fusion of the synaptic vesicle with the plasma membrane involves a complex group of proteins referred to as SNAREs (soluble N-ethylmaleimide sensitive factor attachment protein receptor) [23,24].

The active form of BoNT is a di-chain polypeptide, composed of two chains: a heavy chain (HC) (100 kDa) and a light chain (LC) (50 kDa), associated with auxiliary proteins including haemagglutinins and non-haemagglutinins $[25,26]$. The LC, which is a zinc protease, performs the key action of the toxin by cleaving SNARE proteins [27]. The carboxy-terminal end of the $\mathrm{HC}$ domain binds to a polysialoganglioside receptor on the presynaptic membrane. Likewise, BoNT-A binds to the synaptic vesicle (SV2) protein receptor and BoNT-B to synaptotagmin, both located either inside the exocytosed synaptic vesicle or on the presynaptic membrane. The BoNT is endocytosed inside synaptic vesicles. The LC, in the cytosol, is released from the $\mathrm{HC}$ and cleaves the interchain disulphide bond of the SNARE protein, thus preventing neurotransmitter release and therein leading to neuroparalysis [22].

There are seven immunologically distinct BoNT serotypes (labelled A to G) that cleave specific SNARE proteins. To date, there are only two commercially available BoNT serotypes, botulin toxin type A (BoNT-A) and BoNT type B (BoNT-B). 
Despite limited data from high-quality clinical trials, BoNT-A is considered the treatment of choice for HFS patients [28,29]. Overall, $76 \%$ to $100 \%$ of patients have at least a $75 \%$ improvement with a typical duration of response lasting from 3 to 4 months $[30,31]$. Both primary and secondary HFS patients respond to BoNT-A [10]. Average efficacy has been reported to be around twenty years, often with the need for a gradual increase in dose $[4,30,32]$.

Surgery represents an alternative option for the treatment of HFS. Surgical treatment is a definitive therapy, whereas BoNT provides only a temporary remedy. The first line surgical procedure is microvascular decompression (MVD) of the facial nerve, which consists of removing the compression of the seventh nerve at the root exit zone by the aberrant/ectatic vessel. MVD for HFS was suggested for the first time by Gardner in 1962 [33] and then described further by Jannetta et al. [34].

A standard retrosigmoid craniectomy or craniotomy is used to expose the facial and vestibulocochlear nerves, as well as the lower cranial nerves. The aberrant vessel is identified and dissected away from the facial nerve; shredded Teflon or a Teflon patty is placed between the artery and nerve to assure adequate decompression. Intraoperative neuromonitoring with motor evoked potentials and brainstem auditory evoked potentials is used for making sure that the cranial nerves are functioning and that an adequate de-compression has been obtained. The resolution of an abnormal muscle response on electromyography following decompression confirms the absence of a zone of vascular compression. A recent meta-analysis reported that the overall spasm freedom rate after MVD was $90.5 \%$ at the last follow-up of $1.25 \pm 0.04$ years [35]. The most frequent complications are transient or permanent cranial nerve deficits, leading to hearing loss or facial weakness and CSF leak [35]. The surgical treatment can be reserved for those patients who do not respond to BoNT therapy or desire a long-lasting solution.

\section{Reported Trials-Evidence-Based Medicine}

This review focused on the efficacy and safety of BONT for the treatment of HFS from studies by collecting data from studies published between 1991 to 2021 (Table 1).

From the literature, the efficacy of BONT ranged from $73 \%$ to $98.4 \%$. The mean duration of the effect was around 12 weeks. There were three RCT studies, of which two were conducted to investigate the efficacy and safety of BoNT in HFS [36,37]. The third study compared pretarsal versus preseptal injections of the orbicularis oculi in 31 patients with HFS reporting that the pretarsal portion of the orbicularis oculi was associated with a significantly high response rate in terms of latency to response, duration of improvement, Jankovic Rating Scale (JRS), self-response scale, and patient satisfaction scale than the preseptal injections [38]. The remaining studies were not randomized or prospective. A retrospective longitudinal comparative analysis suggested that the duration of relief from symptoms remains unchanged over the long term in patients with HFS [39]. Moreover, Tunc et al. assessed BoNT injections efficacy in 69 patients with primary HFS $(n=46)$ and those with HFS due to definite neurovascular compression $(n=23)$, reported that primary HFS patients presented more improvement [40] (Table 1).

The second type of study was carried out to compare effectiveness and safety among different formulations of BoNT (Table 2). 
Table 1. Literature review of published articles regarding Botulinum toxin for HFS.

\begin{tabular}{|c|c|c|c|c|c|c|c|c|c|c|c|}
\hline KERRYPNX & Author & Design & $\begin{array}{l}\text { Clinical } \\
\text { Evaluation }\end{array}$ & $n^{\circ}$ & Mean Age & $\begin{array}{l}\text { Disease } \\
\text { Duration }\end{array}$ & End-Point & Improvement & BoNT Type & $\begin{array}{c}\text { Mean } \\
\text { Dosage (UI) }\end{array}$ & $\begin{array}{c}\text { Effect } \\
\text { Duration }\end{array}$ \\
\hline 1 & Yoshimura (1992) [36] & P, RCT, DB & 10-points RS & 11 & 50 & 5.2 year & efficacy and safety & $79 \%$ & Ona & mag-90 & 2.8 month \\
\hline 2 & Berardelli (1993) [41] & $\mathrm{P}, \mathrm{Mc}$ & $\begin{array}{l}\text { Marsden and } \\
\text { Schachter-RS }\end{array}$ & 63 & $\mathrm{n} / \mathrm{a}$ & $\mathrm{n} / \mathrm{a}$ & efficacy & $73-81 \%$ & Ona & $\begin{array}{l}15 \text { to } 40 \\
\text { per eye }\end{array}$ & 11 week \\
\hline 3 & Park (1993) [42] & $\mathrm{P}$ & $0-4$ point RS & 101 & 53.3 & $\begin{array}{l}6 \text { month- } \\
35 \text { year }\end{array}$ & efficacy and safety & $98.4 \%$ & Ona & 13.5 & 16.5 week \\
\hline 4 & $\begin{array}{l}\text { Jitpimolmard } \\
\text { (1998) [2] }\end{array}$ & $\mathrm{P}$ & VAS & 158 & 49.10 & 4 year & $\begin{array}{l}\text { long-term efficacy and } \\
\text { safety }\end{array}$ & $97 \%$ & Abo & 92 & 3.4 month \\
\hline 5 & Thussu (1999) [43] & $\mathrm{P}$ & JRS & 27 & 47.78 & 4.67 year & efficacy & 3.78 & $\begin{array}{l}\text { Abo } \\
\text { Ona }\end{array}$ & $\begin{array}{l}74.37 \\
12.73\end{array}$ & 4.46 month \\
\hline 6 & Trosch (2007) [44] & $\mathrm{P}, \mathrm{OL}$ & VAS & $\begin{array}{l}6 \\
6 \\
6 \\
6\end{array}$ & 60.5 & $\mathrm{n} / \mathrm{a}$ & $\begin{array}{l}\text { safety of BoNT-B and } \\
\text { dose-finding study }\end{array}$ & $\begin{array}{l}4.3(100 \mathrm{UI}) \\
4.7(200 \mathrm{UI}) \\
4.1 \text { (400 UI) } \\
2.2(800 \mathrm{UI})\end{array}$ & Rima & $\begin{array}{l}100 \\
200 \\
400 \\
800\end{array}$ & $\begin{array}{l}\mathrm{n} / \mathrm{a} \\
\mathrm{n} / \mathrm{a} \\
\mathrm{n} / \mathrm{a} \\
\mathrm{n} / \mathrm{a}\end{array}$ \\
\hline 7 & Tunc (2008) [40] & $\mathrm{P}$ & AIMS & $\begin{array}{c}46 \text { (iHFS) } \\
20 \\
\text { (nHFS) }\end{array}$ & $\begin{array}{l}54.4 \\
50.7\end{array}$ & $\begin{array}{l}35.4 \text { month } \\
21 \text { month }\end{array}$ & efficacy (iHFS vs. nHFS) & $\begin{array}{l}2.43 \text { (iHFS) } \\
0.43 \text { (nHFS) }\end{array}$ & ONA & 20 & $\mathrm{n} / \mathrm{a}$ \\
\hline 9 & Rudzinska (2010) [11] & $\mathrm{P}, \mathrm{OL}$ & $\begin{array}{l}\text { CGI-S, BDI, } \\
\text { NMSQ }\end{array}$ & 56 & 60 & $\mathrm{n} / \mathrm{a}$ & $\begin{array}{l}\text { Efficacy (motor and non- } \\
\text { motor symptoms) }\end{array}$ & $75 \%$ & $\begin{array}{c}\text { BONT-A } \\
\text { (Botox-Dysport) }\end{array}$ & $\begin{array}{c}120 \\
\text { (Dysport) } \\
25 \text { (Botox) }\end{array}$ & $\begin{array}{l}\mathrm{n} / \mathrm{a} \\
\mathrm{n} / \mathrm{a}\end{array}$ \\
\hline 10 & Bastola (2010) [46] & $\mathrm{P}$ & JRS & 19 & $\mathrm{n} / \mathrm{a}$ & & efficacy & 3.9 & BONT-A & $\mathrm{n} / \mathrm{a}$ & 5.8 month \\
\hline 11 & Gill (2010) [39] & $\begin{array}{l}\mathrm{R} \text { (early vs. } \\
\text { late) }\end{array}$ & JRS & 16 & 57.6 & 3.8 year & Long-term efficacy & $\mathrm{n} / \mathrm{a}$ & BONT-A & $\begin{array}{c}32.9 \text { (early } \\
\text { sessions) } \\
38.4 \text { (late } \\
\text { sessions) }\end{array}$ & $\begin{array}{c}12.4 \text { week } \\
\text { (early) } \\
12.4 \text { week } \\
\text { (late) }\end{array}$ \\
\hline 12 & Kollewe (2010) [47] & $\mathrm{P}$ & GCI & 97 & $\mathrm{n} / \mathrm{a}$ & $\mathrm{n} / \mathrm{a}$ & Efficacy & 2.6 & $\begin{array}{l}\text { Ona } \\
\text { Abo }\end{array}$ & $\begin{array}{l}22 \\
51\end{array}$ & $\begin{array}{l}12.1 \\
12.2\end{array}$ \\
\hline 13 & Colakoglu (2011) [48] & $\mathrm{R}, \mathrm{SB}, \mathrm{CO}$ & $\begin{array}{l}\text { Clinical } \\
\text { Grading of } \\
\text { Severity in } \\
\text { HFS scale }\end{array}$ & 23 & 61.95 & 9.26 year & $\begin{array}{l}\text { Efficacy into lower facial } \\
\text { muscles }\end{array}$ & $\begin{array}{c}1.88 \\
\text { (mild HFS) } \\
2.35 \\
\text { (severe HFS) } \\
2.56 \\
\text { (orb. oculi) } \\
2.17 \\
\text { (perioral) }\end{array}$ & BONT-A & 16.86 & 15.4 week \\
\hline
\end{tabular}


Table 1. Cont.

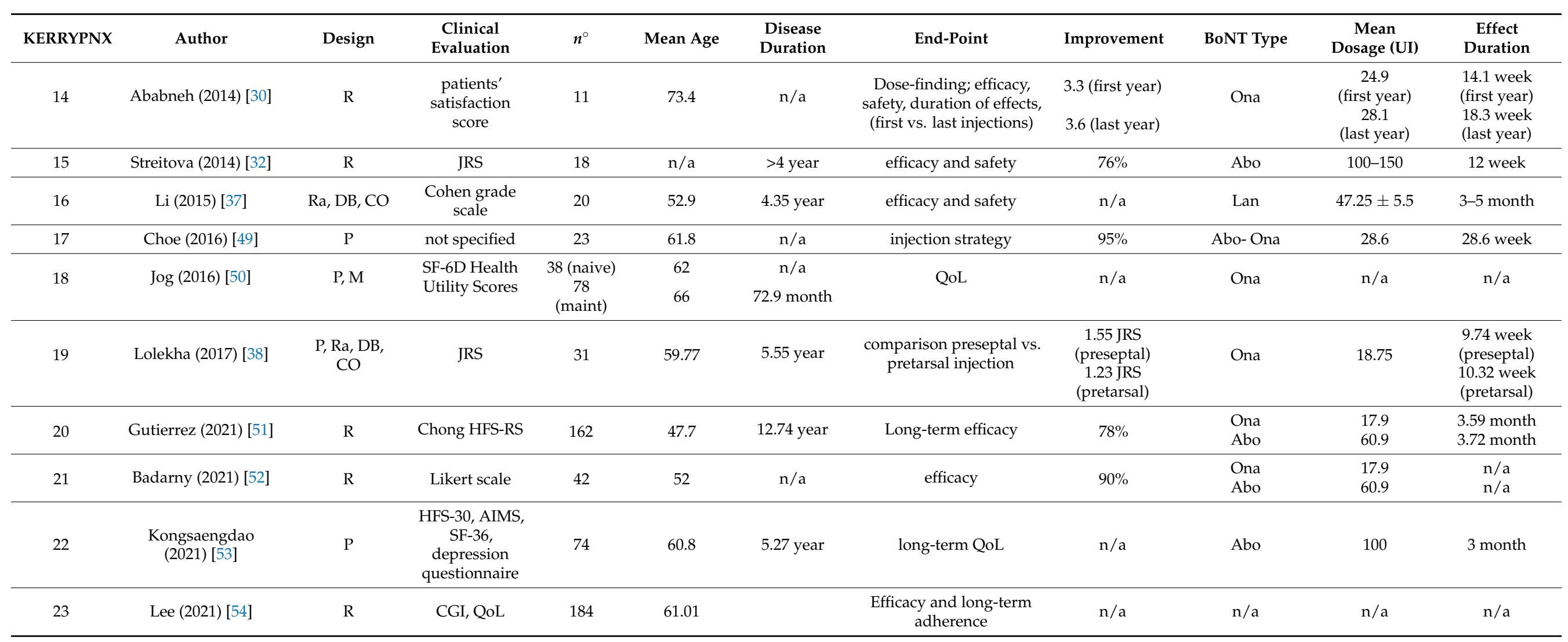

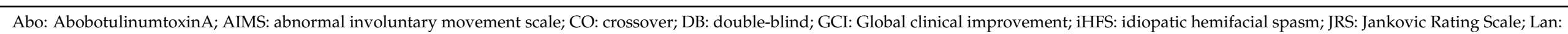

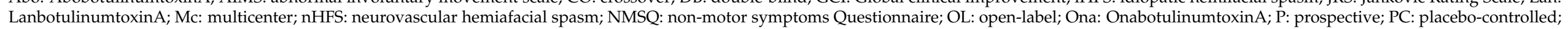
QoL: quality of life; R: retrospective; Ra: randomized; RCT: randomized controlled trial; Rima: Rimabotulinumtoxin-A; RS: rating scale; SB: single-blind; SC: single-center; VAS: visual analogue scale. 
Table 2. BoNT comparative studies in hemifacial spasm.

\begin{tabular}{|c|c|c|c|c|c|c|c|c|c|c|c|c|}
\hline & Author & Design & $\begin{array}{l}\text { Clinical } \\
\text { Evaluation }\end{array}$ & $n^{\circ}$ & $\begin{array}{l}\text { Mean } \\
\text { Age } \\
\text { (years) }\end{array}$ & $\begin{array}{l}\text { Disease } \\
\text { Duration } \\
\text { (years) }\end{array}$ & Comparison & $\begin{array}{c}\text { Conversion } \\
\text { Ratio }\end{array}$ & $\begin{array}{c}\text { Mean } \\
\text { Dosage (UI) }\end{array}$ & Improvement & $\begin{array}{l}\text { Mean Effect } \\
\text { Duration }\end{array}$ & Comments \\
\hline 1 & Marion (1995) [55] & $\mathrm{P}, \mathrm{OL}, \mathrm{DF}$ & $\mathrm{n} / \mathrm{a}$ & 37 & 54.6 & 8.16 & Abo vs. Ona & $3: 1$ & $\begin{array}{l}85 \text { (Abo) } \\
32 \text { (Ona) }\end{array}$ & $\mathrm{n} / \mathrm{a}$ & $\mathrm{n} / \mathrm{a}$ & Similar effects \\
\hline 2 & Sampaio (1996) [56] & $\mathrm{P}, \mathrm{Ra}, \mathrm{SC}, \mathrm{SB}$ & BRS & 49 & $\begin{array}{c}58.2 \\
(\mathrm{Abo}) \\
63.2 \\
\text { (Ona) }\end{array}$ & $\begin{array}{l}6.13 \text { (Abo) } \\
3.99 \text { (Ona) }\end{array}$ & Abo vs. Ona & $1: 4$ & $\mathrm{n} / \mathrm{a}$ & $\mathrm{n} / \mathrm{a}$ & $\begin{array}{l}13.9 \text { weeks (Abo) } \\
13.4 \text { weeks (Ona) }\end{array}$ & Similar effects \\
\hline 4 & Rieder (2007) [58] & $\mathrm{P}, \mathrm{Ra}, \mathrm{CO}, \mathrm{DB}$ & SA & 18 & 60.23 & 8.8 & Lan vs. Ona & $1: 1$ & $\mathrm{n} / \mathrm{a}$ & $\mathrm{n} / \mathrm{a}$ & $\begin{array}{l}72 \text { days (Lan) } \\
71 \text { days (Ona) }\end{array}$ & No differences \\
\hline 5 & Dressler (2009) [59] & $\mathrm{CO}, \mathrm{R} / \mathrm{P}$ & SA & 11 & 61.1 & 6.8 & Ona vs. Inco & $1: 1$ & 43.3 & $\mathrm{n} / \mathrm{a}$ & $\mathrm{n} / \mathrm{a}$ & No differences \\
\hline 6 & $\begin{array}{c}\text { Bentivoglio } \\
\text { (2009) [4] }\end{array}$ & $\mathrm{R}, \mathrm{SC}$ & SA & 108 & 54.1 & 7.9 & Ona vs. Abo & $\mathrm{n} / \mathrm{a}$ & $\begin{array}{l}11.2 \text { (Ona) } \\
46.5 \text { (Abo) }\end{array}$ & $94 \%$ & $\begin{array}{l}105.4 \text { days (Ona) } \\
85.4 \text { days }(\mathrm{Abo})\end{array}$ & No differences \\
\hline 7 & $\begin{array}{c}\text { Quagliato (2010) } \\
\text { [60] }\end{array}$ & P, Ra, DB & HFSES, SF-36 & 17 & 59.8 & 9.1 & Ona vs. Lan & $1: 1$ & 35 & $\mathrm{n} / \mathrm{a}$ & 12.8 weeks & No differences \\
\hline 9 & $\mathrm{Wu}(2011)$ [61] & $\mathrm{P}$ & Cohen's scale & 131 & $\begin{array}{c}45.8 \\
(\mathrm{Lan}) \\
45.3 \\
\text { (Ona) }\end{array}$ & $\mathrm{n} / \mathrm{a}$ & Lan vs. Ona & $1: 1$ & $\mathrm{n} / \mathrm{a}$ & $\begin{array}{l}97 \% \text { (Lan) } \\
94 \% \text { (Ona) }\end{array}$ & $\begin{array}{l}16.2 \text { weeks (Lan) } \\
16.5 \text { weeks (Ona) }\end{array}$ & No differences \\
\hline 10 & $\begin{array}{l}\text { Bentivoglio } \\
(2012)[29]\end{array}$ & $\mathrm{R}, \mathrm{SC}, \mathrm{DF}$ & SA & 10 & 51.6 & 12.3 & Ona vs. Abo & $1: 3-1: 5$ & $\mathrm{n} / \mathrm{a}$ & $\mathrm{n} / \mathrm{a}$ & $\mathrm{n} / \mathrm{a}$ & No differences \\
\hline 11 & Bladen (2020) [62] & $\mathrm{P}, \mathrm{SB}, \mathrm{M}$ & SA & 12 & $\mathrm{n} / \mathrm{a}$ & $\mathrm{n} / \mathrm{a}$ & Ona vs. Inco & $1: 1$ & $\mathrm{n} / \mathrm{a}$ & $\begin{array}{l}84 \% \text { (Inco) } \\
72 \% \text { (Ona) }\end{array}$ & $\begin{array}{l}12 \text { weeks (Inco) } \\
11 \text { weeks (Ona) }\end{array}$ & $\begin{array}{l}\text { More effective } \\
\text { Inco }\end{array}$ \\
\hline 12 & Ozer (2021) [63] & $\mathrm{R}, \mathrm{SC}$ & VAS & 16 & 53.2 & 11 & Ona vs. Abo & $1: 4,95$ & $\mathrm{n} / \mathrm{a}$ & $\mathrm{n} / \mathrm{a}$ & $\mathrm{n} / \mathrm{a}$ & No differences \\
\hline
\end{tabular}

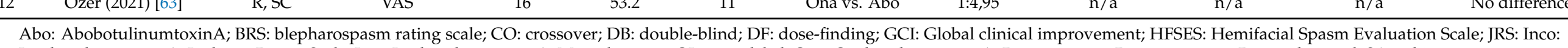

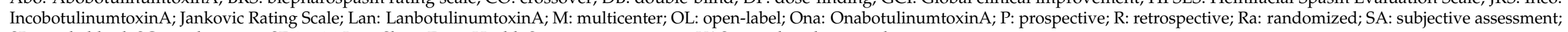
SB: single-blind; SC: single-center; SF-36: 36-Item Short-Form Health Survey questionnaire; VAS: visual analogue scale. 
Of these 12 studies, all investigated OnabotulinumtoxinA. Seven experimental studies explored the clinical differences between OnabotulinumtoxinA vs. AbobotulinumtoxinA. Among these, only one study reported that Ona was superior to Abo in a prospective, singleblind, multicenter study. The only RCT study comparing Ona and Abo did not observe any differences. Among the five remaining, three studies investigated OnabotulinumtoxinA and LanbotulinumtoxinA and two OnabotulinumtoxinA and IncobotulinumtoxinA (Table 2). Inco seemed to have a slightly higher subjective improvement and longer duration of the effect compared to Ona. However, the study included a small number $(=12)$ of patients [62]. A prospective, randomized, double-blind study comparing Lan and Ona reported that these formulations had similar efficacies (mean duration effect: 12.8 vs. 12.9, respectively), no significant difference in safety, along with similar tolerability profiles (excellent for $25.5 \%$ Ona and 5.3\% Lan, good for $64.7 \%$ Ona and $57.9 \%$ Lan), so that a dose equivalence of 1:1 may be considered for HFS treatment [60]. Additionally, Wu et al. compared the therapeutic efficacy and safety profiles of Lan (CBONT-A, Lanzhou Biological Products Institute, China) and Ona for the treatment of HFS, reporting no significant differences in the two rates [61].

\section{Treatment Challenges and Pitfalls}

Botulinum therapy has some limitations. Most importantly, the response rate is high, about $97 \%$ [2]. Moreover, it requires repeated administrations at three- and sixmonths intervals. Even though the safety profile is considered favorable $[30,64]$, adverse effects have been reported, including mild facial paresis (23\%), diplopia (17\%), and ptosis (15\%) [1]. Additionally, trauma from subcutaneous injections can provoke transitory bruising. Regarding systemic adverse effects, flu-like symptoms have been reported in about $14 \%$ of patients within $24 \mathrm{~h}$ after BoNT injection (1.7-20\% of patients treated with BoNT-A and in $5-55 \%$ of those treated with BoNT-B) [43]. The immunoresistance to VTx is unlikely in cases of HFS due to a low dosage employed. The main long-term side effect is facial asymmetry, which can be solved with an injection of the not affected side [37]

Moreover, treatment pitfalls regarding the efficacy and safety of BoNT have known challenges requiring the delivery of tailored dosages and precise identification of target muscles [4]. Other factors that can affect the efficacy of BoNT include volume and dilution, convection, local temperature, and the response of the treated muscle [65,66]. A 10-year follow-up study reported that BONT effectively induced sustained relief from symptoms of HFS over the long-term, with only minimal and transient adverse reactions [3]. Moreover, HFS patients frequently complain of non-motor and motor-related symptoms that can often be relieved by administering BoNT [11]. Finally, another disadvantage of BONT is its high cost [67].

\section{Practical Guidelines of Treatment}

BoNT has to be diluted to a minimal concentration in order to lower its spreading. It is injected via a 30-gauge needle. The muscles involved in HFS include: orbicularis oculi, corrugator supercilii, zygomaticus major, zygomaticus minor, levator labii superioris alaeque nasi, risorius, orbicularis oris, mentalis, depressor anguli oris, and platysma (Figure 1).

In a subgroup of HFS patients, characterized by mild symptomatology, the treatment of orbicularis oculi seemed to be able to control muscle contractions, even in the lower part of the face [4]. This might be due to either the lowering of a triggering spasm from the upper muscles or the spread of the botulinum toxin [48]. In the case of more severe spasms involving the lower facial muscles, a broader treatment targeting the lower facial muscles is recommended [48]. 


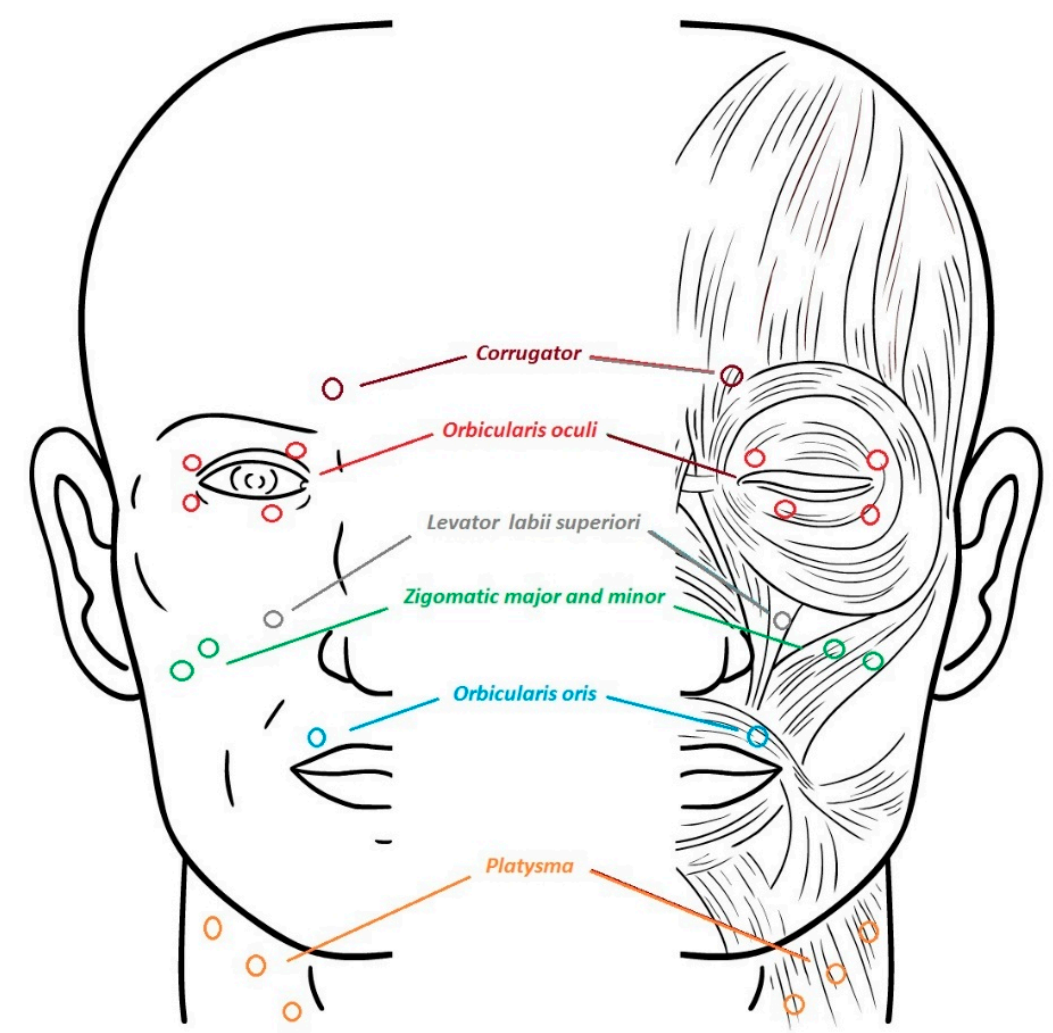

Figure 1. Most frequent treated muscles in hemifacial spasm.

Currently, total doses recommended for HFS for each session should range accordingly: 10-34 U for OnabotulinumtoxinA [68], 53-160 U for AbobotulinumtoxinA [2], and 1250-9000 U for RimabotulinumtoxinB [69]. The therapeutic effect begins at about 3-6 days after treatment and can persist for 2-3 months. Intervals of 3 months between injections are generally recommended. Treatment should be started at low doses and up-titrated, if deemed necessary, depending on the response to therapy.

For HFS, orbicularis oculi injection is similar to that for blepharospasm, although in some patients, injecting the lower portion in the Orbicularis oculi may be sufficient [4]. Specifically, injection of the pretarsal portion may be more effective than preseptal or ocular portion orbicularis oculi injections [38]. Visual inspection is adequate for localizing subcutaneous facial muscles, including orbicularis oculi and platysma. In HFS the problem is to identify from facial expression the muscles and to inject the muscles around the mouth when HFS is severe in the lower territory and keeping at the same time a symmetrical smile. Injection of other facial muscles may first require EMG or electrical stimulation to assure accurate placement.

\section{Proposal for Research and Future Studies}

Presently, international guidelines recommend the use of BoNT for HFS. However, these indications have been based upon observational data. In light of this, randomized trials need to be designed to investigate the factors that influence outcome, including the optimal timing of treatment, injection techniques, dosage and the best selection criteria for formulations. Other aspects that require independent study include patient quality of life, safety, and immunogenicity. The aim of future research should also focus on improving formulations of botulinum toxin, by developing more stable neurotoxins having longer durations and more constant in their efficacy. 
Author Contributions: Conceptualization, M.F. and N.T.; methodology, M.F. and N.T.; resources, M.F. and P.N.; data curation, M.F., P.N., S.S. writing-original draft preparation, M.F. and N.T.; writing-review and editing, L.P., S.S. and N.T. All authors have read and agreed to the published version of the manuscript.

Funding: This research received no external funding.

Institutional Review Board Statement: Not applicable.

Informed Consent Statement: Not applicable.

Acknowledgments: The Movement Disorders Center of the University of Perugia was supported by a grant from the New York University School of Medicine and the Marlene and Paolo Fresco Institute for Parkinson's and Movement Disorders, which was made possible with support from Marlene and Paolo Fresco. We would like to thank Thomas Charles Kilcline for his important editorial assistance. We also thank Matteo Boila for technical support.

Conflicts of Interest: N.T. declares speaking honoraria and travel expenses for attending meetings from Merz and Dysport. M.F., P.N., L.P. and S.S. declare no conflict of interest.

\section{References}

1. Yaltho, T.C.; Jankovic, J. The many faces of hemifacial spasm: Differential diagnosis of unilateral facial spasms. Mov. Disord. 2011, 26, 1582-1592. [CrossRef] [PubMed]

2. Jitpimolmard, S.; Tiamkao, S.; Laopaiboon, M. Long term results of botulinum toxin type A (Dysport) in the treatment of hemifacial spasm: A report of 175 cases. J. Neurol. Neurosurg. Psychiatry 1998, 64, 751-757. [CrossRef] [PubMed]

3. DeFazio, G.; Abbruzzese, G.; Girlanda, P.; Vacca, L.; Currà, A.; De Salvia, R.; Marchese, R.; Raineri, R.; Roselli, F.; Livrea, P.; et al. Botulinum toxin A treatment for primary hemifacial spasm: A 10-year multicenter study. Arch. Neurol. 2002, 59, 418-420. [CrossRef]

4. Bentivoglio, A.R.; Fasano, A.; Ialongo, T.; Soleti, F.; Lo Fermo, S.; Albanese, A. Outcome predictors, ef-ficacy and safety of Botox and Dysport in the long-term treatment of hemifacial spasm. Eur. J. Neurol. 2009, 16, 392-398. [CrossRef]

5. Heuser, K.; Kerty, E.; Eide, P.K.; Cvancarova, M.; Dietrichs, E. Microvascular decompression for hemifacial spasm: Postoperative neurologic follow-up and evaluation of life quality. Eur. J. Neurol. 2007, 14, 335-340. [CrossRef]

6. Schultze, F. Linksseitigerfacialiskrampf in folgeeinesaneurysma der arteria vertebralissinistra. Arch. Pathol. Anat. 1875, 65, 385-391. [CrossRef]

7. Babinski, J. Hémispasme facial périphérique. In Nouvelle Iconographie de la Salpêtrière; Lecrosnier et Babé: Paris, France, 1905; Volume 18, pp. 418-423.

8. Batla, A.; Goyal, C.; Shukla, G.; Goyal, V.; Srivastava, A.; Behari, M. Hemifacial spasm: Clinical characteristics of 321 Indian patients. J. Neurol. 2012, 259, 1561-1565. [CrossRef] [PubMed]

9. Miller, L.E.; Miller, V.M. Safety and effectiveness of microvascular decompression for treatment of hemifacial spasm: A systematic review. Br. J. Neurosurg. 2012, 26, 438-444. [CrossRef]

10. Colosimo, C.; Bologna, M.; Lamberti, S.; Avanzino, L.; Marinelli, L.; Fabbrini, G.; Abbruzzese, G.; DeFazio, G.; Berardelli, A. A Comparative Study of Primary and Secondary Hemifacial Spasm. Arch. Neurol. 2006, 63, 441-444. [CrossRef]

11. Rudzińska, M.; Wójcik, M.; Szczudlik, A. Hemifacial spasm non-motor and motor-related symptoms and their response to botulinum toxin therapy. J. Neural Transm. 2010, 117, 765-772. [CrossRef]

12. Ozzello, D.J.; Giacometti, J.N. Botulinum Toxins for Treating Essential Blepharospasm and Hemifacial Spasm. Int. Ophthalmol. Clin. 2018, 58, 49-61. [CrossRef] [PubMed]

13. Carter, J.B.; Patrinely, J.R.; Jankovic, J.; McCrary, J.A., III; Boniuket, M. Familial hemifacial spasm. Arch. Opthalmol. 1990, 108, 249-250. [CrossRef] [PubMed]

14. Micheli, F.; Scorticati, M.C.; Gatto, E.; Cersosimo, G.; Adi, J. Familial hemifacial spasm. Mov. Disord. 1994, 9, 330-332. [CrossRef]

15. Felício, A.C.; Godeiro-Junior, C.D.O.; Borges, V.; Silva, S.M.D.A.; Ferraz, H.B. Bilateral hemifacial spasm: A series of 10 patients with literature review. Park. Relat. Disord. 2008, 14, 154-156. [CrossRef]

16. Lefaucheur, J.P.; Ben Daamer, N.; Sangla, S.; Le Guerinel, C. Diagnosis of primary hemifacial spasm. Neurochirurgie 2018, 64, 82-86. [CrossRef] [PubMed]

17. Tambasco, N.; Simoni, S.; Sacchini, E.; Eusebi, P.; Marsili, E.; Nigro, P.; Brahimi, E.; Paoletti, F.P.; Romoli, M.; Calabresi, P. Validation of the Hemifacial Spasm Grading Scale: A clinical tool for hemifacial spasm. Neurol. Sci. 2019, 40, 1887-1892. [CrossRef] [PubMed]

18. Tan, E.K.; Fook-Chong, S.; Lum, S.-Y.; Thumboo, J. Validation of a short disease specific quality of life scale for hemifacial spasm: Correlation with SF-36. J. Neurol. Neurosurg. Psychiatry 2005, 76, 1707-1710. [CrossRef]

19. Wabbels, B.; Yaqubi, A. Validation of a new hemifacial spasm grading questionnaire (HFS score) assessing clinical and quality of life parameters. J. Neural Transm. 2021, 128, 793-802. [CrossRef]

20. Bandini, F.; Mazzella, L. Gabapentin as treatment for hemifacial spasm. Eur. Neurol. 1999, 42, 49-51. [CrossRef] 
21. Hallett, M. One man's poison—clinical applications of botulinum toxin. N. Engl. J. Med. 1999, 341, 118-120. [CrossRef]

22. Rossetto, O.; Pirazzini, M.; Montecucco, C. Botulinum neurotoxins: Genetic, structural and mechanistic insights. Nat. Rev. Genet. 2014, 12, 535-549. [CrossRef]

23. Rossetto, O.; Pirazzini, M.; Montecucco, C. Current gaps in basic science knowledge of botulinum neurotoxin biological actions. Toxicon 2015, 107, 59-63. [CrossRef]

24. Pirazzini, M.; Rossetto, O.; Eleopra, R.; Montecucco, C. Botulinum Neurotoxins: Biology, Pharmacology, and Toxicology. Pharmacol. Rev. 2017, 69, 200-235. [CrossRef]

25. Simpson, L.L. Identification of the major steps in botulinum toxin action. Ann. Rev. Pharmacol. Toxicol. 2004, 44, 167-193. [CrossRef]

26. Tambasco, N.; Menichetti, C.; Marchio, A.; Rossi, V.; Pierguidi, L.; Castrioto, A.; Mattucci, E.; Rossi, A. The clinical aspects and the therapeutic use of botulinum toxin in dystonia. In Dystonia: Causes, Symptoms and Treatment; Kurstot, J., Forsström, M., Eds.; Nova Science Publisher: New York, NY, USA, 2010.

27. Pellizzari, R.; Rossetto, O.; Schiavo, G.; Montecucco, C. Tetanus and botulinum neurotoxins: Mechanism of action and therapeutic uses. Philos. Trans. R. Soc. B Biol. Sci. 1999, 354, 259-268. [CrossRef] [PubMed]

28. Jost, W.H.; Kohl, A. Botulinum toxin: Evidence-based medicine criteria in blepharospasm and hemifacial spasm. J. Neurol. 2001, 248, I21-I24. [CrossRef] [PubMed]

29. Bentivoglio, A.R.; Ialongo, T.; Bove, F.; De Nigris, F.; Fasano, A. Retrospective evaluation of the dose equivalence of Botox ${ }^{\circledR}$ and Dysport ${ }^{\circledR}$ in the management of blepharospasm and hemifacial spasm: A novel paradigm for a never ending story. Neurol. Sci. 2012, 33, 261-267. [CrossRef] [PubMed]

30. Ababneh, O.H.; Cetinkaya, A.; Kulwin, D.R. Long-term efficacy and safety of botulinum toxin A injections to treat blepharospasm and hemifacial spasm. Clin. Exp. Ophthalmol. 2014, 42, 254-261. [CrossRef]

31. Hallett, M.; Albanese, A.; Dressler, D.; Segal, K.R.; Simpson, D.M.; Truong, D.; Jankovic, J. Evidence-based review and assessment of botulinum neurotoxin for the treatment of movement disorders. Toxicon 2013, 67, 94-114. [CrossRef]

32. Streitová, H.; Bareš, M. Long-term therapy of benign essential blepharospasm and facial hemispasm with botulinum toxin A: Retrospective assessment of the clinical and quality of life impact in patients treated for more than 15 years. Acta Neurol. Belg. 2014, 114, 285-291. [CrossRef]

33. Gardner, W.J. Concerning the Mechanism of Trigeminal Neuralgia and Hemifacial Spasm. J. Neurosurg. 1962, 19, 947-958. [CrossRef] [PubMed]

34. Jho, H.D.; Jannetta, P.J. Hemifacial Spasm in Young People Treated with Microvascular Decompression of the Facial Nerve. Neurosurg. 1987, 20, 767-770. [CrossRef]

35. Holste, K.; Sahyouni, R.; Teton, Z.; Chan, A.Y.; Englot, D.J.; Rolston, J.D. Spasm Freedom Following Microvascular Decompression for Hemifacial Spasm: Systematic Review and Meta-Analysis. World Neurosurg. 2020, 139, e383-e390. [CrossRef]

36. Yoshimura, D.M.; Aminoff, M.J.; Olney, R.K. Botulinum toxin therapy for limb dystonias. Neurology 1992, 42, 627. [CrossRef]

37. Li, Y.; Huang, Y.; Ding, Q.; Gu, Z.; Pan, X. Evaluation of concentrations of botulinum toxin A for the treatment of hemifacial spasm: A randomized double-blind crossover trial. Genet. Mol. Res. 2015, 14, 1136-1144. [CrossRef]

38. Lolekha, P.; Choolam, A.; Kulkantrakorn, K. A comparative crossover study on the treatment of hemifacial spasm and blepharospasm: Preseptal and pretarsal botulinum toxin injection techniques. Neurol. Sci. 2017, 38, 2031-2036. [CrossRef] [PubMed]

39. Gill, H.S.; Kraft, S.P. Long-Term Efficacy of Botulinum A Toxin for Blepharospasm and Hemifacial Spasm. Can. J. Neurol. Sci. 2010, 37, 631-636. [CrossRef] [PubMed]

40. Tunc, T.; Cavdar, L.; Karadağ, Y.S.; Okuyucu, E.; Coskun, O.; Inan, L.E. Differences in improvement between patients with idiopathic versus neurovascular hemifacial spasm after botulinum toxin treatment. J. Clin. Neurosci. 2008, 15, 253-256. [CrossRef]

41. Berardelli, A.; Formica, A.; Mercuri, B.; Abbruzzese, G.; Agnoli, A.; Agostino, R.; Caraceni, T.; Carella, F.; De Fazio, G.; De Grandis, D.; et al. Botulinum toxin treatment in patients with focal dystonia and hemifacial spasm. A multicenter study of the Italian Movement Disorder Group. Neurol. Sci. 1993, 14, 361-367. [CrossRef] [PubMed]

42. Park, Y.C.; Lim, J.K.; Lee, D.K.; Yi, S.D. Botulinum a toxin treatment of hemifacial spasm and blepharospasm. J. Korean Med Sci. 1993, 8, 334-340. [CrossRef] [PubMed]

43. Thussu, A.; Barman, C.R.; Prabhakar, S. Botulinum toxin treatment of hemifacial spasm and blepharospasm: Objective response evaluation. Neurol. India 1999, 47, 206-209.

44. Trosch, R.M.; Adler, C.H.; Pappert, E.J. Botulinum toxin type B (Myobloc $\left.{ }^{\circledR}\right)$ in subjects with hemifacial spasm: Results from an open-label, dose-escalation safety study. Mov. Disord. 2007, 22, 1258-1264. [CrossRef]

45. Cillino, S.; Raimondi, G.; Guépratte, N.; Damiani, S.; Cillino, M.; Di Pace, F.; Casuccio, A. Long-term efficacy of botulinum toxin A for treatment of blepharospasm, hemifacial spasm, and spastic entropion: A multicentre study using two drug-dose escalation indexes. Eye 2009, 24, 600-607. [CrossRef] [PubMed]

46. Bastola, P.; Chaudhary, M.; Agrawal, J.P.; Shah, D.N. The role of the injection Botulinum Toxin A in cases of Essential Blepharospasm Syndrome, Hemifacial Spasm and Meige's Syndrome. Kathmandu Univ. Med. J. 2012, 8, 305-310. [CrossRef]

47. Kollewe, K.; Mohammadi, B.; Dengler, R.; Dressler, D. Hemifacial spasm and reinnervation synkinesias: Long-term treatment with either Botox ${ }^{\circledR}$ or Dysport ${ }^{\circledR}$. J. Neural Transm. 2010, 117, 759-763. [CrossRef]

48. Colakoglu, B.D.; Cakmur, R.; Uzunel, F. Is it always necessary to apply botulinum toxin into the lower facial muscles in hemifacial spasm? A randomized, single-blind, crossover trial. Eur. Neurol. 2011, 65, 286-290. [CrossRef] [PubMed] 
49. Choe, W.J.; Kim, J. Increasing the area and varying the dosage of Botulinum toxin a injections for effective treatment of hemifacial spasm. Acta Oto-Laryngol. 2016, 136, 952-955. [CrossRef] [PubMed]

50. Jog, M.; Wein, T.; Bhogal, M.; Dhani, S.; Miller, R.; Ismail, F.; Beauchamp, R.; Trentin, G. Real-World, Long-Term Quality of Life Following Therapeutic OnabotulinumtoxinA Treatment. Can. J. Neurol. Sci. 2016, 43, 687-696. [CrossRef]

51. Gutierrez, S.A.S.; Yu, J.R.T.; Yalung, P.M.; Jamora, R.D.G. Real-world experience with botulinum toxin A for the treatment of hemifacial spasm: A study of 1138 injections. Clin. Neurol. Neurosurg. 2021, 205, 106632. [CrossRef]

52. Badarny, S.; Ibrahim, R.; Susel, Z.; Zaina, A.; Nasar, R.; Badarny, Y. Long-term stable efficacy of botulinum toxin A in facial movement disorders with no need for increasing dose. Medicine 2021, 100, e26481. [CrossRef] [PubMed]

53. Kongsaengdao, S.; Maneeton, N.; Maneeton, B. The Five-Year Prospective Study of Quality of Life in Hemifacial Spasm Treated with Abo-Botulinum Toxin A. Toxins 2021, 13, 215. [CrossRef]

54. Lee, J.; Jansen, A.; Samadzadeh, S.; Kahlen, U.; Moll, M.; Ringelstein, M.; Soncin, G.; Bigalke, H.; Aktas, O.; Moldovan, A.; et al. Long-term adherence and response to botulinum toxin in different indications. Ann. Clin. Transl. Neurol. 2021, 8, 15-28. [CrossRef] [PubMed]

55. Marion, M.H.; Sheehy, M.; Sangla, S.; Soulayrol, S. Dose standardisation of botulinum toxin. J. Neurol. Neurosurg. Psychiatry 1995, 59, 102-103. [CrossRef] [PubMed]

56. Sampaio, C.; Ferreira, J.J.; Simões, F.; Rosas, M.J.; Magalhães, M.; Correia, A.P.; Bastos-Lima, A.; Martins, R.; Castro-Caldas, A. DYSBOT: A single-blind, randomized parallel study to determine whether any differences can be detected in the efficacy and tolerability of two formulations of botulinum toxin type A-Dysport and Botox-Assuming a ratio of 4:1. Mov. Disord. 1997, 12, 1013-1018. [CrossRef] [PubMed]

57. Bihari, K. Safety, effectiveness, and duration of effect of BOTOX after switching from Dysport for blepharospasm, cervical dystonia, and hemifacial spasm. Curr. Med. Res. Opin. 2005, 21, 433-438. [CrossRef]

58. Rieder, C.R.; Schestatsky, P.; Socal, M.P.; Monte, T.L.; Fricke, D.; Costa, J.; Picon, P.D. A Double-blind, Randomized, Crossover Study of Prosigne Versus Botox in Patients with Blepharospasm and Hemifacial Spasm. Clin. Neuropharmacol. 2007, 30, 39-42. [CrossRef]

59. Dressler, D. Routine use of Xeomin $\hat{\mathrm{A}}^{\circledR}$ in patients previously treated with Botox $\hat{\mathrm{A}}^{\circledR}$ : Long term results. Eur. J. Neurol. 2009, 16, 2-5. [CrossRef]

60. Quagliato, E.M.A.B.; Carelli, E.F.; Viana, M.A. Prospective, Randomized, Double-Blind Study, Comparing Botulinum Toxins Type A Botox and Prosigne for Blepharospasm and Hemifacial Spasm Treatment. Clin. Neuropharmacol. 2010, 33, 27-31. [CrossRef]

61. Wu, C.J.; Shen, J.H.; Chen, Y.; Lian, Y.J. Comparison of two different formulations of botulinum toxin A for the treatment of blepharospasm and hemifacial spasm. Turk. Neurosurg. 2011, 21, 625-629. [CrossRef]

62. Bladen, J.C.; Favor, M.; Litwin, A.; Malhotra, R. Switchover study of onabotulinumtoxinA to incobotulinumtoxinA for facial dystonia. Clin. Exp. Ophthalmol. 2020, 48, 1146-1151. [CrossRef]

63. Ozer, I.S.; Kumcu, M.K.; Aydemir, S.T.; Akbostanci, M.C. Dose conversion ratio, comparative efficacy, and adverse events after switching from onabotulinum toxin A to abobotulinum toxin A for neurological conditions. Clin. Neurol. Neurosurg. 2021, 209, 106889. [CrossRef] [PubMed]

64. Herrero-Infante, Y.; Rodríguez-Sanz, A.; Máñez-Miró, J.; Vivancos-Matellano, F. Hemifacial spasm through the last three decades: From etiology to efficacy and safety of long-term botulinum toxin treatment. Clin. Neurol. Neurosurg. 2021, 203, 106555. [CrossRef]

65. Hallett, M. Explanation of timing of botulinum neurotoxin effects, onset and duration, and clinical ways of influencing them. Toxicon 2015, 107, 64-67. [CrossRef] [PubMed]

66. Koshy, J.C.; Sharabi, S.E.; Feldman, E.M.; Hollier, L.H., Jr.; Patrinely, J.R.; Soparkar, C.N. Effect of dietary zinc and phytase supplementation on botulinum toxin treatments. J. Drugs Dermatol. 2012, 11, 507-512.

67. Dodel, R.C.; Kirchner, A.; Koehne-Volland, R.; Künig, R.G.; Ceballos-Baumann, A.; Naumann, M.; Brashear, A.; Richter, H.P.; Szucs, T.D.; Oertel, W.H. Costs of Treating Dystonias and Hemifacial Spasm with Botulinum Toxin A. Pharmacoeconomics 1997, 12, 695-706. [CrossRef]

68. Mezaki, T.; Kaji, R.; Kimura, J.; Ogawa, N. Treatment of hemifacial spasm with type A botulinum toxin (AGN 191622): A dose finding study and the evaluation of clinical effect with electromyography. No Shinkei Brain Nerve 1999, 51, 427-432. [PubMed]

69. Wan, X.-H.; Vuong, K.D.; Jankovic, J. Clinical application of botulinum toxin type B in movement disorders and autonomic symptoms. Chin. Med. Sci. J. 2005, 20, 44-47. 